\title{
Effect of preceding crop on the agronomic and economic performance of durum wheat in the transition from conventional to reduced tillage
}

\author{
Laura Ercoli $^{\mathrm{a}, *}$, Alessandro Masoni ${ }^{\mathrm{b}}$, Marco Mariotti ${ }^{\mathrm{c}}$, Silvia Pampana ${ }^{\mathrm{b}}$, Elisa Pellegrino ${ }^{\mathrm{a}}$, Iduna Arduini ${ }^{\mathrm{b}}$ \\ a Institute of Life Sciences, Scuola Superiore Sant'Anna, Piazza Martiri della Libertà 33, 56127 Pisa, Italy \\ b Department of Agriculture, Food and Environment, University of Pisa, via del Borghetto 80, 56124 Pisa, Italy \\ ${ }^{c}$ Department of Veterinary Science, University of Pisa, viale delle Piagge 2, 56124 Pisa, Italy
}

\section{A R T I C L E I N F O}

\section{Article history:}

Received 3 July 2015

Received in revised form 12 October 2016

Accepted 18 October 2016

Available online xxx

Keywords:

Durum wheat

Crop preceding wheat

Soil tillage

Economic profitability

\begin{abstract}
A B S T R A C T
Preceding crop greatly affects the agronomic and economic performance of durum wheat, but its interaction with tillage intensity was scarcely investigated at the early transition from conventional to reduced tillage. This work was aimed at studying how preceding crop determines the performance of durum wheat during the early transition from conventional to reduced tillage. To this end, the effect of four preceding crops (sunflower, durum wheat, alfalfa and maize) in interaction with two tillage systems without inversion (RT1 - chisel ploughing, disking twice, and harrowing and RT2 - disking twice and harrowing) and a conventional tillage (CT - mouldboard ploughing, disking twice, and harrowing) was studied on durum wheat in two years of cultivation. The effect of preceding crop on grain yield and yield components of durum wheat was different depending on tillage intensity, and this effect varied depending on the year of cultivation. Grain yield increased by $1.1-4.2 \mathrm{t} \mathrm{ha}^{-1}$ with the increase of the intensity of tillage in both years and all preceding crops, with the only exception of wheat crop following sunflower in 2009-2010 and following maize in 2010-2011. RT2 decreased wheat grain yield when compared with RT1 only with alfalfa as preceding crop. Differences in grain yield among tillage systems and crops preceding wheat in both years were mainly due to variations of mean kernel weight and number of spikes per unit area. The profitability of durum wheat varied according to the year of cultivation, the preceding crop and the tillage system. Overall, in both years profitability was lowest and negative following wheat under reduced tillage system, while it was highest and positive following alfalfa under CT. Reduced growth of durum wheat with reduced tillage systems was mainly consequence of weeds and volunteers plants development and nitrogen availability in soil resulting from nutrient immobilization. It can be concluded that potential yield penalties in durum wheat in the transition from conventional to reduced tillage can be alleviated by an appropriate selection of preceding crops.
\end{abstract}

(C) 2016 Published by Elsevier Ltd.

\section{Introduction}

Durum wheat is a major crop for agricultural production in Italy, with a total area of $1,287,565$ ha in 2014 (ISTAT, 2015). Since from 2013 European Union subsidies to agriculture production have been removed, the only way for producers to remain financially viable is through efficient production. Higher efficiency represents the ability to produce more output with the lowest invest in inputs (Coelli et al., 2005). Thus, producers need to achieve the economic optimal level of production, which is when the maximum difference between revenue and costs is attained (Tozer, 2010).

Conservation tillage involves soil management practices that minimise the disruption of the soil's structure, composition and natural biodiversity, thereby minimising erosion and degradation as well as water contamination (Lal et al., 1998; Holland, 2004). Conservation tillage encompasses any non-inversion soil cultivation technique that leaves sufficient crop residues in place to cover at least $30 \%$ of the soil surface after sowing (Lal, 2003), and it is often adopted for cost saving, because it decreases manpower and energy required for crop

\footnotetext{
* Corresponding author.

Email address: ercoli@sssup.it (L. Ercoli)
}

cultivation, and for soil conservation and moisture retention (Kassam et al., 2009).

Tillage affects soil physical, chemical and biological properties, as well as plant growth, root distribution into soil, and ultimately crop yield (Holland et al., 2004). Owing to the intrinsic variability in climatic conditions, soil characteristics and management practices, contradictory yield results have been reported in comparisons between conservation and conventional tillage systems (e.g., Mazzoncini et al., 2008; Giacomini et al., 2010). Yield increases under reduced tillage were recorded in sandy soils and dry conditions due to higher soil water availability, whereas yield disadvantages in clay and loam soils and humid conditions due to reduced plant establishment and increased development of pests and weeds (Ercoli et al., 2006; Van den Putte et al., 2010; Giller et al., 2015). It is often reported that the positive effects of reduced tillage or no tillage on grain yield and soil properties only become apparent after several years (e.g., Hao et al., 2002; Madejon et al., 2009). In the long-term soil fertility is improved, but changes in $\mathrm{C}$ stock in soil occur slowly, being relevant only in the long-term (Lal et al., 1998; González-Prieto et al., 2013). However, recent evidences question the potential for $\mathrm{C}$-sequestration of reduced tillage systems, as differences were limited to the distribution of soil organic carbon (SOC), with higher concentrations near the surface under conservation tillage and in deeper layers under con- 
ventional tillage (Baker et al., 2007; Powlson et al., 2011). By contrast, in the early transition stage, from standard to reduced tillage systems, variations in SOC following the change of soil management are not expected, but yield reductions can occur following the short-term nitrogen $(\mathrm{N})$ immobilization and the reduced weed control (Karlen et al., 1994; Kong et al., 2009).

A considerable volume of the literature has addressed the effects of preceding crop on wheat (e.g. Bennett et al., 2012; Mazzilli et al., 2016), but the effect of preceding crop in interaction with tillage intensity was scarcely investigated both at the early transition from conventional to reduced tillage and in the long term. In the long tem grain yield following legumes and fallow was similar under no-tillage and conventional tillage, whereas following wheat no-till wheat was more productive (López-Bellido et al., 2007, 2012). In addition, at planting, soil water storage and nitrate content in soil were lower under no tillage following sunflower compared to fallow, legumes and wheat (López-Bellido et al., 2007, 2013).

Therefore, our research was carried out to study, during the transition from conventional to reduced tillage, the effects of different preceding crops (i.e., sunflower, durum wheat, alfalfa and maize) and tillage intensities on the agronomic and economic performance of durum wheat.

\section{Materials and methods}

\subsection{Site description and climatic data}

A field experiment was carried out at the experimental station of the Department of Agriculture, Food and Environment of the Univer- sity of Pisa, Italy, which is located at a distance of approximately $3 \mathrm{~km}$ from the sea $\left(43^{\circ} 40^{\prime} \mathrm{N}, 10^{\circ} 19^{\prime} \mathrm{E}\right)$ and $1 \mathrm{~m}$ above sea level.

Main soil physical and chemical properties were: $403 \mathrm{~g} \mathrm{~kg}^{-1}$ sand; $358 \mathrm{~g} \mathrm{~kg}^{-1}$ silt; $239 \mathrm{~g} \mathrm{~kg}^{-1}$ clay; $7.2 \mathrm{pH} ; 18.3 \mathrm{~g} \mathrm{~kg}^{-1}$ organic matter; $0.9 \mathrm{~g} \mathrm{~kg}^{-1}$ total $\mathrm{N} ; 10.0 \mathrm{mg} \mathrm{kg}^{-1}$ available $\mathrm{P}$ (Olsen method); $166 \mathrm{mg} \mathrm{kg}^{-1}$ available K (Dirks-Sheffer method). Soil texture was loam and soil type Typic Xerofluvents, according to the USDA soil taxonomy (Soil Survey Staff, 2010).

At the experimental site, the climate was characterised as cold humid Mediterranean with 120-year average of mean annual maximum and minimum daily air temperatures of $20.2^{\circ} \mathrm{C}$ and $9.5^{\circ} \mathrm{C}$, respectively, and annual precipitation of $971 \mathrm{~mm}$, with $663 \mathrm{~mm}$ received during the period of durum wheat cultivation (from November to June). The weather data were collected from a weather station located within $500 \mathrm{~m}$ of the experimental site. Rainfall varied yearly over the two wheat-cropping seasons: in 2009-2010 it was similar to the 120-year average in the area (Moonen et al., 2002; Vallebona et al., 2014), whereas in 2010-2011 it was 45\% lower than the 120 -year average (Fig. 1). In 2009-2010, rainfall was well distributed through the wheat cycle and thus was more favourable for wheat growth and development. By contrast, the cropping season 2010-2011 was particularly dry, especially in the period following heading. Temperature was generally higher in 2009-2010. During the 10-days prior to anthesis, when active cell division in the ovary occurs, the mean maximum temperature was $24.2^{\circ} \mathrm{C}$ in 2010 and $19.2^{\circ} \mathrm{C}$ in 2011 .

\subsection{Experimental design}

The experiment was established to evaluate the impact of preceding crop and tillage intensity on the production and profitability of
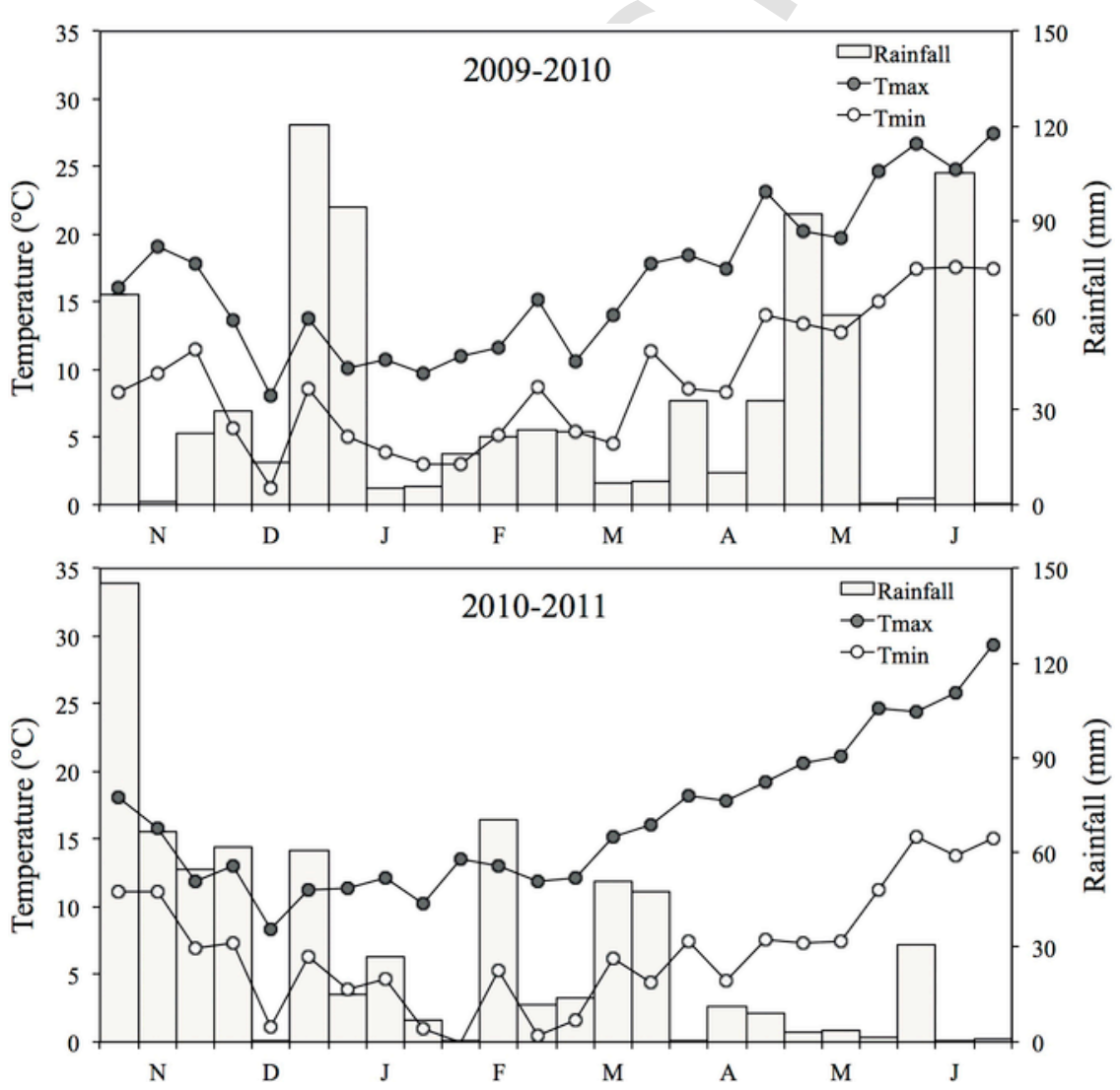

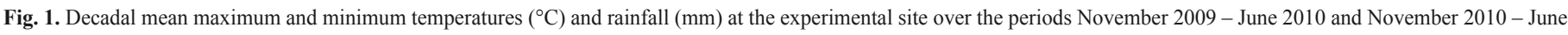
2011. 
durum wheat. In order to test the impact of the preceding crop, such as maize, sunflower, alfalfa and durum wheat, we utilised a long-term field study established in spring 2005 that compares in time and space at field level (ca. $2500 \mathrm{~m}^{2}$ ha per field replicate, $\mathrm{n}=3$ ) two arable crop rotations (maize-durum wheat and sunflower-durum wheat), a fodder crop rotation (maize-durum wheat-alfalfa-alfalfa-alfalfa-durum wheat), and a continuous durum wheat. Sunflower, maize and durum wheat were grown for grain, whereas alfalfa was grown for hay with four cuts per year. The biomass left in the field was approximately $600,500,700$ and $400 \mathrm{~g} \mathrm{~m}^{-2}$ of dry weight for sunflower, alfalfa, maize and durum wheat, respectively. Crops were managed following the common agronomical technique applied in the area, comprising conventional tillage (mouldboard ploughing, disking twice, and harrowing). Wheat was harvested in early July, maize in mid-September, sunflower in early August, and alfalfa was terminated in early October.

In the autumn before durum wheat sowing (2009-11-24 and 2010-12-16) two reduced tillage systems without inversion (RT1 chisel ploughing, disking twice, and harrowing and RT2 - disking twice and harrowing) and a conventional tillage system (CT - mouldboard ploughing, disking twice, and harrowing) were set up in each field replicate previously cultivated with sunflower, durum wheat, alfalfa and maize. CT represents the control, where there was no transition from conventional to reduced tillage. The conventional tillage system was performed with a 3-bottom general purposed mouldboard plough equipped with share points ploughing to a nominal depth of $40 \mathrm{~cm}$, followed by disking twice with a tandem disc to a nominal depth of $15 \mathrm{~cm}$ and surface rotary harrowing to a nominal depth of $20 \mathrm{~cm}$ for seedbed preparation. RT1 was performed with a chisel plough equipped with $40 \mathrm{~cm}$ sweeps followed by disking twice with a tandem disc to a nominal depth of $15 \mathrm{~cm}$ and surface rotary harrowing to a depth of $20 \mathrm{~cm}$ before sowing. RT2 consisted of disking twice and harrowing as above. Crop residues were not removed and were incorporated to a 40-cm depth under CT and RT1 and at 20-cm depth under RT2. The durum wheat variety Levante (Breeder: Produttori Sementi Spa, Bologna, Italy) was grown for the two years of cultivation (2009-2010 and 2010-2011) on all the combinations of preceding crop and tillage system. Levante is one of the most widely grown varieties in Central Italy, was released in 2002 and is medium maturing and is characterised by high yellow index, very high protein concentration and medium gluten quality.

In each year of cultivation, the experimental design was a two-factorial split-plot with three replications. The main plot factor was the preceding crop (sunflower, durum wheat, alfalfa and maize) and the subplot factor was the tillage system (CT, RT1, RT2). The area of each replicated subplot was $150 \mathrm{~m}^{2}$.

Apart from tillage, management was the same in all the treatments. Phosphorus and $\mathrm{K}$ were applied immediately before soil tillage as triple mineral phosphate $\left(\mathrm{Ca}\left(\mathrm{H}_{2} \mathrm{PO}_{4}\right)_{2} \cdot \mathrm{H}_{2} \mathrm{O}\right)$ and potassium sulphate $\left(\mathrm{K}_{2} \mathrm{SO}_{4}\right)$, at rates of $35 \mathrm{~kg} \mathrm{ha}^{-1} \mathrm{P}$ and $66 \mathrm{~kg} \mathrm{ha}^{-1} \mathrm{~K}$. Nitrogen was applied at $150 \mathrm{~kg} \mathrm{~N} \mathrm{ha}^{-1}$, split into three doses of 30,60 and $60 \mathrm{~kg} \mathrm{~N} \mathrm{ha}^{-1}$, the first before soil harrowing as ammonium sulphate and the others as urea at pseudo-stem erection and at first node detectable. Growth stages of pseudo stem erection and first node detectable were determined following the scale of Zadoks (Zadoks et al., 1974), corresponding to GS30 and GS31, respectively. The N, P and $\mathrm{K}$ fertiliser rates were calculated on the basis of the balance approach. In detail, fertiliser rates were calculated to cover the crop N, $\mathrm{P}$ and $\mathrm{K}$ demand for a grain yield of ca. $6 \mathrm{Mg} \mathrm{ha}^{-1}$ with $13.5 \%$ protein content in grain, taking into account the balance outputs-inputs (i.e. leaching, denitrification and mineralization). Durum wheat was sown on 2009-11-25 and 2010-12-17 by a Vignoli precision hydraulic seed drill in rows $15 \mathrm{~cm}$ apart at the rate of 400 viable seeds $\mathrm{m}^{-2}$.
Weed control was achieved with a pre-emergence application of trifluralin. No disease or insect treatment was applied.

\subsection{Data collection and analyses}

Soil samples (0-40 cm depth) were collected in November 2009 and December 2010 before wheat sowing. Five soil cores were obtained from each experimental plot $(n=3)$ where sunflower, durum wheat, alfalfa and maize were grown since 2005. Samples were thoroughly mixed, air-dried, ground, sieved at $2 \mathrm{~mm}$ and then analysed for nitrate $\mathrm{N}$ by the ion-selective electrode method, following extraction with double distilled $\mathrm{H}_{2} \mathrm{O}$ (Keeney and Nelson, 1982).

At physiological maturity (2010-6-22 and 2011-6-30) plants from a $1-\mathrm{m}^{2}$ area were manually cut at ground level and partitioned into wheat and weeds. Wheat plants were partitioned into culms, leaves, chaff and grain. For dry weight determination, samples of all plant parts of wheat and of weeds were oven dried at $65^{\circ} \mathrm{C}$ up to constant weight. The number of spikes per unit area, mean kernel weight, number of spikelets per spike, number of kernels per spike were measured at maturity. Samples of each plant part were analysed for $\mathrm{N}$ concentration (modified Kjeldahl method, Bremner and Mulvaney, 1982). Nitrogen contents were calculated by multiplying the $\mathrm{N}$ concentration by the dry weight. Since the effects of treatments were similar on leaves, culms and chaff, data were combined together and hereafter referred to as residues. Spike fertility index (SFI) was calculated following the method of Abbate et al. (2013) as the quotient between grain number $\mathrm{m}^{-2}$ and spike chaff dry weight $\mathrm{m}^{-2}$ at maturity. Durum wheat plots were evaluated for disease incidence and severity by a visual assessment of symptoms of fungal infection.

Soil samples were collected in July 2010 and 2011 at a depth of $0-40 \mathrm{~cm}$ following the wheat harvest. Five soil cores were obtained from each experimental plot (preceding crop and tillage system). Samples were thoroughly mixed and analysed for nitrate $\mathrm{N}$ as described above.

Profitability $(\mathrm{P})$ of wheat under different tillage and preceding crop was calculated as follows:

$\mathrm{P}=\mathrm{p} * \mathrm{Y}-\mathrm{IC}$

where $\mathrm{p}\left(€ \mathrm{t}^{-1}\right)$ is the grain price; $\mathrm{Y}$ is the grain yield $\left(\mathrm{t} \mathrm{ha}{ }^{-1}\right)$; IC is the input costs $\left(€ \mathrm{ha}^{-1}\right)$. The input costs used for the gross margin analyses are presented in Table 1. The input prices for seed, fertiliser

Table 1

Variable costs used to calculate profitability for wheat crop.

\begin{tabular}{|c|c|c|c|c|}
\hline Class & Description & Rate & $\begin{array}{l}\text { Unit cost } \\
\left(€ \mathrm{~kg} \mathrm{~L}^{-1}\right)\end{array}$ & $\begin{array}{l}\text { Cost per hectare } \\
\left(€ \text { ha }^{-1}\right)\end{array}$ \\
\hline \multirow{7}{*}{$\begin{array}{l}\text { Contractor } \\
\text { cost }\end{array}$} & Soil tillage $-\mathrm{CT}$ & & & 186.90 \\
\hline & Soil tillage - RT1 & & & 123.90 \\
\hline & Soil tillage - RT2 & & & 78.40 \\
\hline & Seeding & & & 36.40 \\
\hline & $\begin{array}{l}\text { Herbicide } \\
\text { application }\end{array}$ & & & 37.10 \\
\hline & $\begin{array}{l}\text { Fertiliser } \\
\text { application }\end{array}$ & & & 23.80 \\
\hline & Harvesting & & & 106.40 \\
\hline Seed & & $200 \mathrm{~kg} \mathrm{ha}^{-1}$ & 0.68 & 136.00 \\
\hline Herbicide & Glyphosate $\left.^{(}\right)$ & $2 \mathrm{~L} \mathrm{ha}^{-1}$ & 5.00 & 10.00 \\
\hline $\begin{array}{l}\text { Fertiliser } \\
(\mathrm{N})\end{array}$ & Urea & $326 \mathrm{~kg} \mathrm{ha}^{-1}$ & 0.52 & 169.50 \\
\hline Fertiliser $(\mathrm{P})$ & $\begin{array}{l}\text { Triple mineral } \\
\text { phosphate }\end{array}$ & $174 \mathrm{~kg} \mathrm{ha}^{-1}$ & 0.70 & 121.80 \\
\hline $\begin{array}{l}\text { Fertiliser } \\
(\mathrm{K})\end{array}$ & Potassium sulphate & $160 \mathrm{~kg} \mathrm{ha}^{-1}$ & 0.70 & 112.00 \\
\hline
\end{tabular}


and fuel were calculated from the average prices of the Italian market in the period 2009-2011. The operating costs for cultural practices, including all costs that can be assigned to field operations (e.g. fuel, variable machinery costs and labour costs, as well as fixed machinery costs) were estimated based on average contractor rates for the period 2009-2011. In detail, the contractor rates were reduced by $30 \%$, thus including operating costs and overheads and excluding contractor profit. Fixed costs, such as land rental rate costs, were not included in the calculation of profitability. To isolate production-related effects from market effects, the wheat price used in the analysis was $281.66 € \mathrm{t}^{-1}$ grain, calculated as the average price in the years 2007-2013 at the Bologna market, which is the reference market for Central-Northern Italy.

\subsection{Statistical analysis}

Data were analysed by a three-way ANOVA (analysis of variance), where replicates and years (Y) were regarded as random effects and preceding crops (Prec) and tillage system (Till) as fixed effects. The year was considered as a random variable, due to unpredictable weather conditions under rainfed Mediterranean conditions (Gomez and Gomez, 1984). Data were ln- and arcsine-transformed when needed to fulfil the assumptions of the ANOVA. Means given in tables and figures are for untransformed data. Significantly different means were separated at the 0.05 probability level by the least significant difference test (LSD) (Steel et al., 1997). All the analyses were performed using the SPSS software package version 21.0 (SPSS Inc., Chicago, IL, USA).

\section{Results}

\subsection{Pre-planting and post-harvest nitrate $N$ content in soil}

The level of nitrate $\mathrm{N}$ content at sowing in the $0-40 \mathrm{~cm}$ soil layer was significantly higher when alfalfa was used as preceding crop and lower when the preceding crop was wheat, being on average by $30 \mathrm{~kg} \mathrm{ha}^{-1}$ higher (Fig. 2). The post-harvest nitrate $\mathrm{N}$ content in soil was overall lower than that at sowing, but was similarly affected by the preceding crops (Fig. 2). Differences in nitrate $\mathrm{N}$ content in soil averaged $10.4 \mathrm{~kg} \mathrm{~N} \mathrm{ha}^{-1}$ comparing alfalfa and wheat as preceding crop. In addition, tillage system affected nitrate $\mathrm{N}$ accumulation, which was significantly higher in CT than in RT1 and RT2 (Fig. 2). In detail, these differences corresponded to $4 \mathrm{~kg} \mathrm{~N}^{-1}$ when CT was compared with RT1 and to $8.4 \mathrm{~kg} \mathrm{~N} \mathrm{ha}^{-1}$ when it was compared with RT2. Finally, the year of cultivation significantly affected post-har-
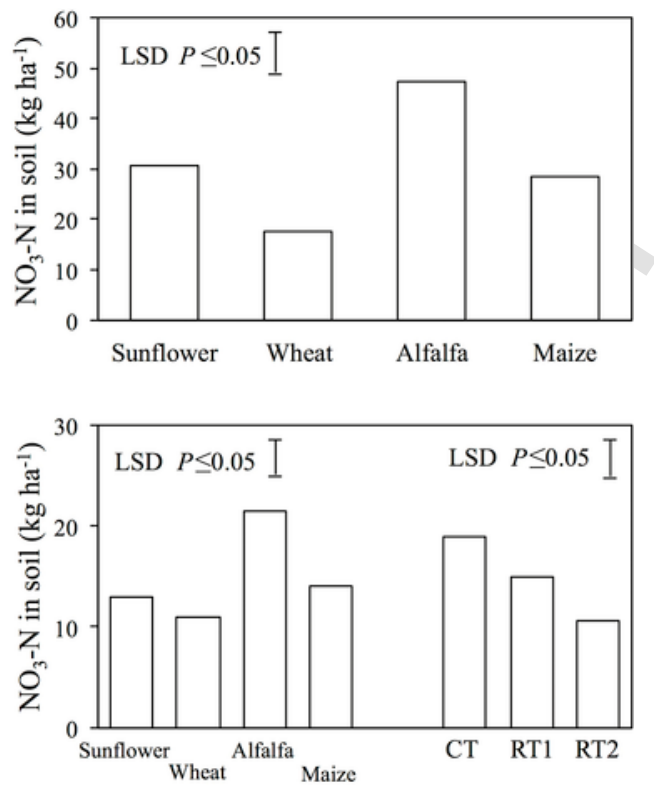

Fig. 2. Mean effect of preceding crop on preplant residual nitrate $\mathrm{N}$ content in soil (up) and mean effects of preceding crop and tillage system on residual nitrate $\mathrm{N}$ content in soil after crop harvest (down). Least significant difference (LSD) among preceding crop and tillage system means are shown at $P \leq 0.05$.

vest nitrate $\mathrm{N}$ content in soil (Table 2), which was by $14 \%$ lower in 2010-2011 comparing to 2009-2010 (results not shown).

\subsection{Grain yield and yield components}

Grain yield of durum wheat was significantly affected by the interaction year of cultivation $\mathrm{x}$ preceding crop $\mathrm{x}$ tillage system, indicating that the effect of the preceding crop was different depending on the tillage method, and this varied depending on the year (Table 2). In both years, grain yield greatly decreased with the decrease of the intensity of tillage with alfalfa and wheat as preceding crops, while with sunflower and maize grain yield was not affected by tillage (Fig. 3). No statistically significant difference on grain yield was recorded in both years between RT1 and RT2 with all preceding crops except alfalfa, where the yield reduction increased with the decrease of the intensity of tillage.

The number of spikes per unit area was significantly affected by the interactions preceding crop $\mathrm{x}$ tillage system and preceding crop $\mathrm{x}$

Table 2

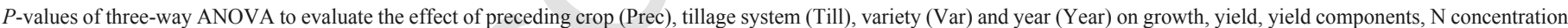
in grain and residues, nitrate $\mathrm{N}$ in soil and crop profitability of durum wheat.

\begin{tabular}{|c|c|c|c|c|c|c|c|c|c|c|c|}
\hline $\begin{array}{l}\text { Source of } \\
\text { variation }^{\text {a }}\end{array}$ & $\begin{array}{l}\text { Grain } \\
\text { yield }\end{array}$ & $\begin{array}{l}\text { Weeds } \\
\text { dry } \\
\text { weight }\end{array}$ & $\begin{array}{l}\text { Number } \\
\text { of spikes }\end{array}$ & $\begin{array}{l}\text { Number of } \\
\text { kernels per } \\
\text { spike }\end{array}$ & $\begin{array}{l}\text { Mean } \\
\text { kernel } \\
\text { weight }\end{array}$ & $\begin{array}{l}\text { Spike } \\
\text { fertility } \\
\text { index }\end{array}$ & $\begin{array}{l}\text { Grain N } \\
\text { concentration }\end{array}$ & $\begin{array}{l}\text { Residues N } \\
\text { concentration }\end{array}$ & $\begin{array}{l}\text { Plant N } \\
\text { content }\end{array}$ & $\begin{array}{l}\text { Post harvest } \\
\text { nitrate } \mathrm{N} \\
\text { content in soil }\end{array}$ & $\begin{array}{l}\text { Crop } \\
\text { profitability }\end{array}$ \\
\hline $\operatorname{Prec}^{\mathrm{b}}$ & $<0.001^{\mathrm{c}}$ & $<0.001$ & $<0.001$ & $<0.001$ & $<0.001$ & $<0.001$ & $<0.001$ & 0.003 & $<0.001$ & $<0.001$ & $<0.001$ \\
\hline Till $^{\mathrm{d}}$ & $<0.001$ & $<0.001$ & $<0.001$ & $<0.001$ & 0.937 & $<0.001$ & 0.678 & 0.113 & $<0.001$ & $<0.001$ & $<0.001$ \\
\hline Year $^{\mathrm{e}}$ & $<0.001$ & $<0.001$ & $<0.001$ & 0.002 & $<0.001$ & $<0.001$ & 0.04 & 0.001 & $<0.001$ & $<0.001$ & $<0.001$ \\
\hline Prec $\times$ Till & $<0.001$ & 0.031 & 0.042 & $<0.001$ & 0.001 & $<0.001$ & $<0.001$ & 0.032 & $<0.001$ & 0.238 & $<0.001$ \\
\hline Prec $\times$ Year & $<0.001$ & 0.037 & 0.007 & 0.003 & $<0.001$ & $<0.001$ & $<0.001$ & 0.001 & $<0.001$ & 0.155 & $<0.001$ \\
\hline Till $\times$ Year & 0.008 & 0.068 & 0.273 & 0.196 & 0.019 & 0.328 & 0.466 & 0.010 & 0.279 & 0.306 & $<0.001$ \\
\hline Prec $\times$ Till $\times$ Year & 0.035 & 0.973 & 0.175 & $<0.001$ & 0.016 & 0.016 & 0.007 & 0.107 & 0.034 & 0.137 & 0.072 \\
\hline
\end{tabular}

${ }^{\text {a }}$ Prec, and Var used as fixed factors, Year as random factor.

b Preceding crops: sunflower, wheat, alfalfa, maize.

${ }^{\mathbf{c}}$ In bold statistically significant values $(P \leq 0.05)$. Replicates field plots were three per treatment.

d Tillage systems: CT, conventional system; RT1, chisel ploughing, disking twice, and harrowing; RT2, disking twice and harrowing.

e 2009-2010 and 2010-2011 cropping cycles. 


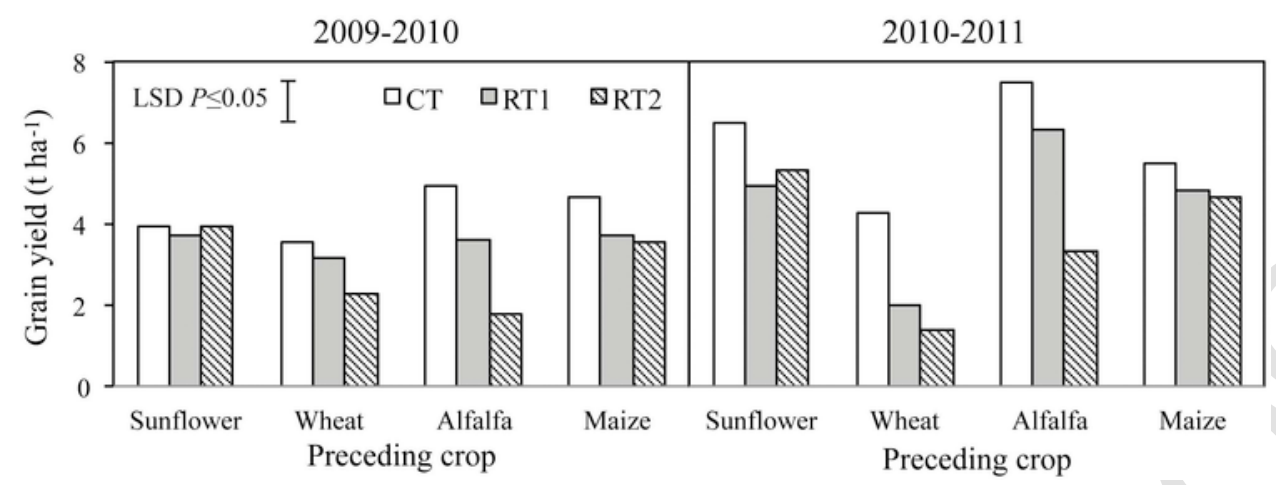

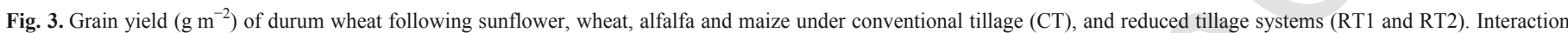
year $\mathrm{x}$ preceding crop $\mathrm{x}$ tillage system. Least significant difference (LSD) among year, preceding crop and tillage system means are shown at $P \leq 0.05$.

year (Table 2). The number of spikes per unit area was reduced with

Table 3

Number of spikes and weeds dry weight of durum wheat. Preceding crop x tillage system interaction.

\begin{tabular}{|c|c|c|c|c|}
\hline Tillage System $^{\mathrm{a}}$ & Sunflower & Wheat & Alfalfa & Maize \\
\hline & \multicolumn{4}{|c|}{ Number of spikes $\mathrm{m}^{-2}$} \\
\hline $\mathrm{CT}$ & 357.1 & 268.0 & 330.8 & 379.1 \\
\hline RT1 & 330.5 & 268.0 & 278.2 & 375.3 \\
\hline RT2 & 353.6 & 194.4 & 211.1 & 319.6 \\
\hline \multirow{2}{*}{$\mathrm{LSD}_{\text {Prec } \times \text { Till }}$} & \multirow{2}{*}{\multicolumn{4}{|c|}{$\begin{array}{l}74.3 \\
\text { Weeds dry weight }\left(\mathrm{g} \mathrm{m}^{-2}\right)\end{array}$}} \\
\hline & & & & \\
\hline $\mathrm{CT}$ & 45.1 & 90.6 & 60.5 & 25.0 \\
\hline RT1 & 42.9 & 174.6 & 96.7 & 41.6 \\
\hline RT2 & 66.4 & 165.8 & 200.8 & 50.1 \\
\hline $\mathrm{LSD}_{\text {Prec }} \times$ Till & 85.5 & & & \\
\hline
\end{tabular}

${ }^{a}$ Prec used as fixed factors, Year as random factor.

Table 4

Number of spikes and weeds dry weight of durum wheat. Preceding crop x year interaction.

\begin{tabular}{|c|c|c|c|c|}
\hline Year $^{\mathrm{a}}$ & Sunflower & Wheat & Alfalfa & Maize \\
\hline & \multicolumn{3}{|c|}{ Number of spikes $\mathrm{m}^{-2}$} & \\
\hline 2009-2010 & 370.7 & 292.6 & 267.1 & 383.4 \\
\hline 2010-2011 & 323.4 & 194.3 & 279.6 & 332.6 \\
\hline \multirow{2}{*}{ LSD $_{\text {Prec } \times \text { Year }}{ }^{b}$} & 60.7 & & & \\
\hline & Weeds dry & $\left(\mathrm{g} \mathrm{m}^{-2}\right)$ & & \multirow{4}{*}{$\begin{array}{l}59.3 \\
18.5\end{array}$} \\
\hline 2009-2010 & 81.7 & 208.6 & 177.4 & \\
\hline 2010-2011 & 21.3 & 78.8 & 61.2 & \\
\hline $\mathrm{LSD}_{\text {Prec }} \times$ Till & 69.8 & & & \\
\hline
\end{tabular}

${ }^{\text {a }}$ Prec used as fixed factors, Year as random factor.
RT1 and RT2 compared to CT when the crop preceding wheat was wheat and alfalfa, while it was not affected when sunflower and maize were the preceding crops (Table 3). Moreover, the preceding crop did not significantly affect the number of spikes in the two years, with the only exception for wheat, which reduced it by 34\% in 2010-2011 (Table 4). The number of kernels per spike was increased under CT with all crops preceding wheat in both years, except for sunflower in 2009-2010 and maize in 2010-2011 (Table 5). No significant difference in the number of kernels per spike between RT1 and RT2 was recorded under all preceding crops in both years, with the only exception for alfalfa in 2010-2011.

Mean kernel weight was affected by the interaction year x preceding crop $\mathrm{x}$ tillage system (Table 2). Overall, mean kernel weight was $27 \%$ lower in 2009-2010 compared to 2010-2011, whereas differences due to tillage system were not significant at all preceding crops in both years, with the exception of wheat and maize as preceding crops in 2009-2010. In detail, in 2009-2010 mean kernel weight following wheat significantly decreased from CT to RT1 and RT2, while following maize it significantly increased from CT and RT1 to RT2 (Table 5).

Spike fertility index (SFI) was affected by the interaction year $\mathrm{x}$ preceding crop $x$ tillage system (Table 2). In both years, SFI was not affected by tillage system with all crops preceding wheat, except for alfalfa. In detail, SFI decreased significantly with RT2 in comparison with CT and RT1 and the reduction was higher in 2009-2010 compared to 2010-2011 (Table 5).

\subsection{Nitrogen uptake by wheat}

Grain $\mathrm{N}$ concentration was affected by the interaction year $\mathrm{x}$ preceding crop $\mathrm{x}$ tillage system (Table 2). In 2009-2010, highest values were recorded following wheat and alfalfa; while in 2010-2011 high-

Table 5

Number of spikes, mean kernel weight and spike fertility index of durum wheat. Year, tillage systemy and preceding crop interaction.

\begin{tabular}{|c|c|c|c|c|c|c|c|c|c|c|c|c|c|}
\hline \multirow[t]{2}{*}{ Year $^{\mathrm{a}}$} & \multirow[t]{2}{*}{ Tillage system } & \multicolumn{4}{|c|}{ Number of kernels per spike } & \multicolumn{4}{|c|}{ Mean kernel weight (mg) } & \multicolumn{4}{|c|}{ Spike fertility index (n. kernels $\mathrm{g}^{-1}$ ) } \\
\hline & & Sunflower & Wheat & Alfalfa & Maize & Sunflower & Wheat & Alfalfa & Maize & Sunflower & Wheat & Alfalfa & Maize \\
\hline \multirow[t]{6}{*}{ 2009-2010 } & $\mathrm{CT}^{\mathrm{b}}$ & 26.6 & 32.8 & 48.7 & 32.1 & 36.8 & 36.4 & 34.5 & 38.2 & 20.9 & 21.2 & 33.8 & 23.6 \\
\hline & RT1 & 27.1 & 26.8 & 34.3 & 22.5 & 39.2 & 36.9 & 36.5 & 40.0 & 20.2 & 18.5 & 33.6 & 18.7 \\
\hline & RT2 & 28.3 & 24.6 & 24.5 & 25.3 & 39.3 & 36.3 & 33.4 & 40.3 & 21.1 & 20.7 & 20.4 & 20.7 \\
\hline & CT & 40.3 & 35.2 & 37.6 & 29.6 & 51.4 & 51.5 & 54.4 & 49.0 & 17.3 & 19.1 & 19.6 & 17.7 \\
\hline & RT1 & 30.2 & 20.1 & 46.3 & 29.2 & 53.1 & 46.7 & 51.4 & 49.8 & 15.3 & 15.5 & 20.6 & 17.0 \\
\hline & RT2 & 30.6 & 23.7 & 30.5 & 29.7 & 50.0 & 46.2 & 53.2 & 54.6 & 16.9 & 16.6 & 14.7 & 16.0 \\
\hline \multicolumn{14}{|c|}{$\operatorname{LSD}_{\text {Year }} \times{ }_{\text {Till } \times \text { Prec }}^{c}$} \\
\hline
\end{tabular}


est values were recorded following alfalfa (Table 6). The reduction of tillage intensity at RT2 significantly increased grain N concentration of durum wheat grown following maize in both years. Nitrogen concentration in residues was affected by the interactions preceding crop $\mathrm{x}$ year, tillage system $\mathrm{x}$ year, and preceding crop $\mathrm{x}$ tillage system, but the magnitude of the differences among treatments were small and were considered to be insignificant with regard to crop $\mathrm{N}$ uptake (results not shown). Plant $\mathrm{N}$ content of durum wheat was significantly affected by the interaction year of cultivation $\mathrm{x}$ preceding crop $\mathrm{x}$ tillage system, indicating that the effect of the preceding crop was different depending on the tillage method, and this varied depending on the year (Table 2). When alfalfa and wheat were the preceding crops, the reduction of tillage intensity from CT to RT1 and RT2 greatly and progressively decreased plant $\mathrm{N}$ content of durum wheat, whereas with sunflower and maize plant $\mathrm{N}$ content was not significantly affected by tillage system (Table 6).

\subsection{Weed development}

Weed development was significantly affected by the interactions preceding crop $\mathrm{x}$ tillage system and preceding crop x year (Table 2). Weed biomass in durum wheat at physiological maturity was not affected by tillage system when maize and sunflower were the preceding crops, while it increased with the decrease of tillage intensity following wheat and alfalfa (Table 3). In 2009-2010 weed biomass in wheat crop was higher compared to 201-2011, and increased when wheat and alfalfa were the preceding crops. Conversely, in 2010-2011, weed growth did not vary according to the preceding crop (Table 4).

Weeds varied both in specific composition and plant density according to the preceding crop and tillage system (results not shown). With maize, sunflower and wheat as preceding crops we observed the typical species of the weed flora of central Italy arable fields (e.g., Lolium spp., Avena spp., Calistegia spp.), whereas following alfalfa the regrowth of alfalfa in the wheat crop occurred especially in RT2 plots, since alfalfa growth was only partially suppressed by the tillage.

\subsection{Economic analysis}

The sum of total variable costs, comprising the costs of field management operations and of seeds, herbicides and fertilizers was $939 € \mathrm{ha}^{-1}$ under CT. Total variable costs were reduced by 7 and $12 \%$ under RT1 and RT2, respectively (Table 1).

The profitability of durum wheat, calculated as the difference between crop income and variable costs, varied according to the interactions preceding crop $\mathrm{x}$ year, tillage system $\mathrm{x}$ year, and preceding crop $\mathrm{x}$ tillage system, owing to variations in both costs and crop in- come (Fig. 4). Overall, in both years profitability was lowest and negative following wheat, while it was positive under the other preceding crops with higher values in 2010-2011 compared to 2009-2010. The reduction of tillage intensity reduced profitability in both years, but the decreases were higher in 2010-2011. Finally, the reduction of profitability associated to the decrease of tillage intensity from CT to RT1 and RT2 was small when sunflower and maize were the preceding crops, and high with wheat and alfalfa as preceding crop. The combinations preceding crop/tillage system as wheat/RT1, wheat/RT2 and alfalfa/RT2 resulted in negative profitability (Fig. 4).

\section{Discussion}

In both years, the general trend of decreased grain yield with decreased tillage intensity varied depending on preceding crop, but in the season 2009-2010 climatic conditions were less favourable for grain growth and the effect of tillage was less pronounced. Averaged over all treatments, grain yield was $3.6 \mathrm{t} \mathrm{ha}^{-1}$ in $2009-2010$ and $4.7 \mathrm{tha}^{-1}$ in 2010-2011 and differences in the yield performance between years were primarily due to mean kernel weight that was on average by $27 \%$ lower in 2009-2010. The number of spikes per $\mathrm{m}^{2}$, which was $14 \%$ higher in 2009-2010, could not compensate for the lower value of mean kernel weight. This result suggest that in 2009-2010 environmental conditions during the initial phases of the crop developmental cycle were more favourable for crop establishment, tiller development and spike development, but were less favourable in the last part of the cycle, probably in response to the strong competition for resources by weeds, which were poorly controlled by herbicides. Differential climatic conditions between years also affected kernel set within the spike. The lower spike fertility index recorded in 2010-2011 was likely attributed to water deficit during the phase of florets fecundation, reducing the frequency of grain setting by florets (Ercoli et al., 2008). In agreement with the results of Calderini et al. (1999) on bread wheat and of Ferrise et al. (2010) on durum wheat, in our study the lower mean kernel wheat recorded in 2009-2010 could also be attributed to the high mean daily maximum temperature calculated for the 15 days prior to anthesis, which reduced the rate of endosperm division in the ovary and hence the final size of durum wheat grains.

In the present study, it was shown that the effect of tillage system in the early transition from conventional to reduced tillage varied with preceding crop. Reduced tillage (RT2) had a great grain yield disadvantage respect to $\mathrm{CT}$ when durum wheat followed alfalfa and wheat, whereas differences among tillage systems were smaller when sunflower and maize were the preceding crops. The effects of tillage system and preceding crop on the productivity of wheat in Mediterranean climate have been widely reported (e.g., De Sanctis et al., 2012; López-Bellido et al., 2012), but the effect of preceding crop in

Table 6

Number of spikes, mean kernel weight and spike fertility index of durum wheat. Year, tillage systemy and preceding crop interaction.

\begin{tabular}{|c|c|c|c|c|c|c|c|c|c|}
\hline \multirow[t]{2}{*}{ Year $^{\mathrm{a}}$} & \multirow[t]{2}{*}{ Tillage system } & \multicolumn{4}{|c|}{ Grain $\mathrm{N}$ concentration $\left(\mathrm{g} \mathrm{kg}^{-1}\right)$} & \multicolumn{4}{|c|}{ Plant $\mathrm{N}$ content $\left(\mathrm{kg} \mathrm{ha}^{-1}\right)$} \\
\hline & & Sunflower & Wheat & Alfalfa & Maize & Sunflower & Wheat & Alfalfa & Maize \\
\hline \multirow[t]{3}{*}{ 2009-2010 } & $\mathrm{CT}^{\mathrm{b}}$ & 19.1 & 21.2 & 20.7 & 19.8 & 102.9 & 111.0 & 120.5 & 113.6 \\
\hline & RT1 & 18.8 & 23.9 & 22.6 & 18.3 & 86.2 & 97.8 & 94.8 & 88.3 \\
\hline & RT2 & 16.2 & 22.0 & 21.7 & 21.2 & 87.1 & 67.6 & 48.8 & 99.0 \\
\hline \multirow[t]{3}{*}{ 2010-2011 } & $\mathrm{CT}$ & 18.6 & 19.7 & 23.2 & 17.6 & 145.2 & 100.9 & 195.0 & 113.3 \\
\hline & RT1 & 19.1 & 20.4 & 22.0 & 17.5 & 114.3 & 51.6 & 161.7 & 106.6 \\
\hline & RT2 & 19.7 & 18.0 & 20.6 & 21.7 & 128.5 & 32.8 & 83.8 & 120.2 \\
\hline \multicolumn{2}{|c|}{$\operatorname{LSD}_{\text {Year } \times \text { Till } \times \text { Prec }}{ }^{c}$} & 2.9 & & & & 29.9 & & & \\
\hline
\end{tabular}

a used as fixed factors, year used as random factor.

b Tillage systems: CT, conventional system; RT1, chisel ploughing, disking twice, and harrowing; RT2, disking twice and harrowing.

c Least significant difference among year, Till and Prec means at $P \leq 0.05$. 

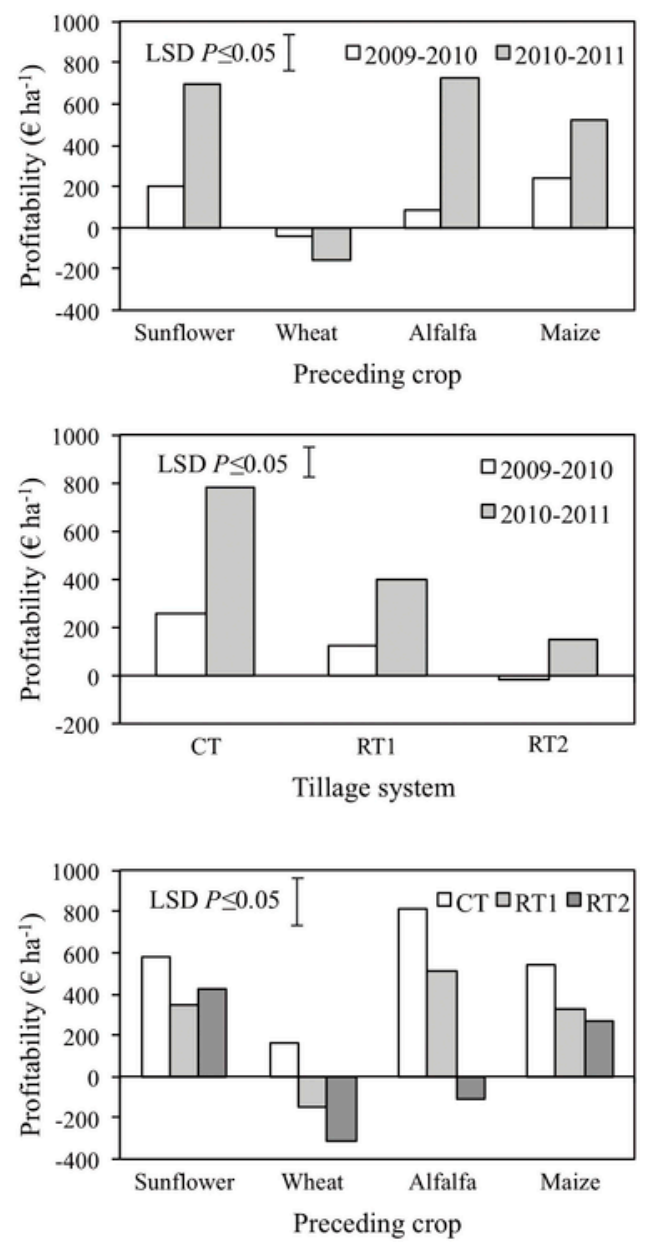

Fig. 4. Profitability of wheat crop $\left(€ \mathrm{ha}^{-1}\right)$ following sunflower, wheat, alfalfa and maize under conventional tillage (CT), and reduced tillage systems (RT1 and RT2) in 2009-2010 and 2010-2011. Interaction year x preceding crop (up), year x tillage system (centre) and tillage system $\mathrm{x}$ preceding crop (down). Least significant difference (LSD) among year, preceding crop and tillage system means are shown at $P \leq 0.05$.

interaction with tillage intensity was scarcely investigated at the early transition from conventional to reduced tillage. Observed differences among tillage systems depending on preceding crop may be related to three main factors: crop traits associated with the emergence of vigorous seedlings and subsequent plant growth; weeds and volunteers plants development; nutrients availability in soil resulting from nutrients immobilization and losses. All these factors affect plant competition ability and use of resources. Van den Putte et al. (2010) attributed the yield advantage from deep conservation tillage in comparison with superficial conservation tillage to the increased plant growth, owing to benefits from the increased pore space and aeration at greater depths. The higher number of spikes in CT when compared with RT1 and RT2 suggest improved crop establishment, tillering and tiller survival with conventional tillage. In addition, the reduction of the number of spikes per unit area when the preceding crop was wheat may reveal a toxic effect of allelochemicals released by the wheat residues that affect the establishment and development of the following wheat crop (Sieling et al., 2005; Ercoli et al., 2007, 2014). Further cause of yield reduction was high weed development, since the negative effect of reduced tillage on yield was greater in preceding crops promoting weed growth. Yield reductions were particularly severe when alfalfa was the preceding crop, as shallow tillage treat- ments could not effectively control in-crop alfalfa growth. This is an indication that in reduced tillage systems, during the transition period, mechanical soil disturbance and herbicide rate and timing designed for CT is not sufficient to control weeds. Consequently, with changing tillage systems, cropping managements aimed to achieve effective weed control have also to be changed accordingly. Indeed, following Halde et al. (2015) and Nichols et al. (2015), additional innovative soil and weed management practices are needed to implement reduced tillage systems based on non inversion of soil, i.e. modified seeding systems aiming to eliminate problems of seed establishment.

Preceding crop and tillage intensity influenced wheat demand for nutrients and nutrient supply from the soil. The reduction of tillage intensity lead to a decreased plant $\mathrm{N}$ content when alfalfa and wheat were the preceding crops, whereas with sunflower and maize as preceding crop plant $\mathrm{N}$ content was not significantly affected by tillage system. Lower net $\mathrm{N}$ mineralization rate and hence nitrate $\mathrm{N}$ is generally available for crops when they are grown under no tillage or reduced tillage, due to slower mineralization and higher $\mathrm{N}$ immobilization and nitrification (Alvarez and Steinbach, 2009; López-Bellido et al., 2013). It is generally recommended to increase $\mathrm{N}$ fertilization in reduced tillage during the transition period, as this system can alter both crop demand for $\mathrm{N}$, due to changes in yield potential and $\mathrm{N}$ supply, and $\mathrm{N}$ immobilization by soil microbes (Pekrun et al., 2003; Pellegrino et al., 2015; Ciccolini et al., 2016). In this regard, Kong et al. (2009) found that already within the first year of transition from conventional to reduced tillage, under reduced tillage there was a greater potential for increased $\mathrm{N}$ stabilization and reduced $\mathrm{N}$ losses compared to the conventional tillage.

In dry climates reduced tillage systems for cereals are potentially better than conventional tillage systems, because they ensure a greater availability of water to the crops (Bonfil et al., 1999; Bescansa et al., 2006; De Vita et al., 2007). In the dry Mediterranean climate, Amato et al. (2013) found that the effects of tillage intensity on durum wheat varied greatly according to the crop water stress index (WSI). When the WSI was high, grain yield was greater with the conservative tillage than with the conventional tillage, whereas the opposite was true when the WSI was low. Our results obtained in a humid Mediterranean environment support the view that higher rainfall results in more negative effects of the conservation practices on wheat grain yield. Similarly, Giller et al. (2015) reported yield penalty in no till treatments compared to minimum tillage in wetter seasons $(>300 \mathrm{~mm})$, whereas little difference were recorded in dry seasons $(<250 \mathrm{~mm})$. The great yield advantage obtained under $\mathrm{CT}$ is likely to be associated to adequate water availability and benefits from improved crop nutrition and weed control. However, potential yield penalties under RT when environmental conditions are not favourable can be alleviated by the choice of an adequate preceding crop, such as maize or sunflower.

The main driver for conservation tillage adoption is the time, labour and fuel savings and the consequent potential for greater economic returns offered by this technology. Thus, from an economic point of view, yield increases/losses have to be evaluated against inputs (reduced labour hours/fuel input). A large volume of literature has addressed the issue of reducing tillage intensity without depressing yield, since the adoption of conservation tillage will crucially depend on its economic viability (Baker et al., 2004). Moreover, the transition from an existing system to alternative systems can determine economic obstacles that prevent the adoption, even if alternative systems would be viable in the long term (Archer et al., 2007). Management adjustments for improving crop mineral nutrition and weed control may increase input costs, inhibiting the adoption of the re- 
duced tillage systems in the short term (Krause and Black, 1995). In this regard, our results showed that the tillage intensity significantly interacts with wheat preceding crops. Durum wheat following maize and sunflower were the least affected by the tillage system. Overall, wheat preceding wheat, irrespective of tillage system, is generally not advisable, due to the low crop income, and CT is the best option when alfalfa is the preceding crop. With maize or sunflower as preceding crop, deep reduced tillage (RT1) may be equivalent or only slightly lower in profitability compared to CT, while shallow tillage (RT2) reduced durum wheat profitability with all preceding crops except sunflower.

\section{Conclusions}

The results of the present experiment, performed during the transitioning from conventional to reduced tillage under rainfed Mediterranean conditions, show that the response of durum wheat to tillage system in terms of production and profitability varied according to weather conditions and crop sequence. Conventional tillage guaranteed superior wheat grain yield compared to RT1 and RT2 when alfalfa and wheat were the preceding crops, while, following sunflower and maize, tillage intensity could be reduced without any significant reduction on grain yield. Yield gap between the conventional and the reduced tillage systems was greater when the climatic conditions were more favourable for wheat and weed growth. Reduced growth of durum wheat with reduced tillage systems were mainly consequence of weed and volunteer plant development and $\mathrm{N}$ availability in soil due to its decreased mineralization. These results suggest that changes in weed control and $\mathrm{N}$ fertiliser management are required in the first year of transition. Finally, the present research supports practical recommendations for farmers in order to select the most suitable crops during the early transition phase from conventional to reduced tillage.

\section{References}

Abbate, P.E., Pontaroli, A.C., Lazaro, L., Gutheim, F., 2013. A method of screening for spike fertility in wheat. J. Agric. Sci. 151, 322-330.

Alvarez, R., Steinbach, H.S., 2009. A review of the effects of tillage systems on some soil physical properties, water content, nitrate availability and crops yield in the Argentine Pampas. Soil Till. Res. 104, 1-15.

Amato, G., Ruisi, P., Frenda, A.S., Di Miceli, G., Saia, S., Plaia, A., Giambalvo, D., 2013. Long-term tillage and crop sequence effects on wheat grain yield and quality. Agron. J. 105, 1317-1327.

Archer, D.W., Jaradat, A.A., Johnson, J.M., Weyers, S.L., Gesch, R.W., Forcella, F., Kludze, H.K., 2007. Crop productivity and economics during the transition to alternative cropping systems. Agron. J. 99, 1538-1547.

Baker, D.A., Young, D.L., Huggins, D.R., Pan, W.L., 2004. Economically optimal nitrogen fertilization for yield and protein in hard red spring wheat. Agron. J. 96, 116-123.

Baker, J.M., Ochsner, T.E., Venterea, R.T., Griffis, T.J., 2007. Tillage and carbon sequestration-what do we really know?. Agric. Ecosyst. Environ. 118, 1-4.

Bennett, A.J., Bending, G.D., Chandler, D., Hilton, S., Mills, P., 2012. Meeting the demand for crop production: the challenge of yield decline in crops grown in short rotations. Biol. Rev. 87, 52-71.

Bescansa, P., Imaz, M.J., Virto, I., Enrique, A., Hoogmoed, W.B., 2006. Soil water retention as affected by tillage and residue management in semiarid Spain. Soil Till. Res. 87, 19-27.

Bonfil, D.J., Mufradi, I., Klitman, S., Asido, S., 1999. Wheat grain yield and soil profile water distribution in a no-till arid environment. Agron. J. 91, 368-373.

Bremner, J.M., Mulvaney, C.S., 1982. In: second ed., In: Page, A.L., Miller, R.H., Keeney, D.R. (Eds.), Nitrogen - Total Methods of Soil Analysis, Part 2, Chemical , Microbiological Properties, Agronomy Monograph. vol. 9. American Society of Agronomy, Madison, WI, pp. 595-624.

Calderini, D.F., Abeledo, L.G., Savin, R., Slafer, G.A., 1999. Effect of temperature and carpel size during pre-anthesis on potential grain weight in wheat. J. Agric. Sci. 132, 453-459.

Ciccolini, V., Bonari, E., Ercoli, L., Pellegrino, E., 2016. Phylogenetic and multivariate analyses to determine the effect of agricultural land-use intensification and soil physico-chemical properties on N-cycling communities in drained Mediterranean peaty soils. Biol. Fertil. Soils 52, 811-824.

Coelli, T.J., PrasadaRao, D.S., O’Donnell, C.J., Battese, G.E., 2005. An Introduction to Efficiency and Productivity Analysis, 2nd ed. Springer, New York.

De Sanctis, G., Roggero, P.P., Seddaiu, G., Orsini, R., Porter, C.H., Jones, J.W., 2012. Long-term no tillage increased soil organic carbon content of rain-fed cereals ystems in a Mediterranean area. Eur. J. Agron. 40, 18-27.

De Vita, P., Di Paolo, E., Fecondo, G., Di Fonzo, N., Pisante, M., 2007. No tillage and conventional tillage effects on durum wheat yield: grain quality and soil moisture content in southern Italy. Soil Till. Res. 92, 69-78.

Ercoli, L., Masoni, A., Mariotti, M., Arduini, I., 2006. Dry matter accumulation and remobilization of durum wheat as affected by soil gravel content. Cereal Res. Commun. 34, 1299-1306.

Ercoli, L., Masoni, A., Pampana, S., Arduini, I., 2007. Allelopathic effects of rye, brown mustard and hairy vetch on redroot pigweed: common lambsquarter and knotweed. Allelopath. J. 19, 249-256.

Ercoli, L., Lulli, L., Mariotti, M., Masoni, A., Arduini, I., 2008. Post-anthesis dry matter and nitrogen dynamics in durum wheat as affected by nitrogen supply and soil water availability. Eur. J. Agron. 28, 138-147.

Ercoli, L., Masoni, A., Pampana, S., Mariotti, M., Arduini, I., 2014. The response of durum wheat to the preceding crop in a mediterranean environment. Sci. World J. 2014, (Article ID 717562).

Ferrise, R., Triossi, A., Stratonovitch, P., Bindi, M., Martre, P., 2010. Sowing date and nitrogen fertilisation effects on dry matter and nitrogen dynamics for durum wheat: an experimental and simulation study. Field Crops Res. 117, 245-257.

Giacomini, S.J., Machet, J.M., Boizard, H., Recous, S., 2010. Dynamics and recovery of fertilizer $15 \mathrm{~N}$ in soil and winter wheat crop under minimum versus conventional tillage. Soil Till. Res. 108, 51-58.

Giller, K.E., Andersson, J.A., Corbeels, M., Kirkegaard, J., Mortensen, D., Erenstein, O., Vanlauwe, B., 2015. Beyond conservation agriculture. Front. Plant Sci. 6.

Gomez, K.A., Gomez, A.A., 1984. Statistical Procedures for Agricultural Research. John Wiley \& Sons, New York.

González-Prieto, S., Díaz-Raviña, M., Martín, A., López-Fando, C., 2013. Effects of agricultural management on chemical and biochemical properties of a semiarid soil from central Spain. Soil Till. Res. 134, 49-55.

Halde, C., Bamford, K.C., Entz, M.H., 2015. Crop agronomic performance under a six-year continuous organic no-till system and other tilled and conventionally-managed systems in the northern Great Plains of Canada. Agric. Ecosyst. Environ. 213, 121-130.

Hao, Y., Lal, R., Owens, L.B., Izaurralde, R.C., Post, W.M., Hothem, D.L., 2002. Effect of cropland management and slope position on soil organic carbon pool at the North Appalachian experimental watersheds. Soil Till. Res. 68, 133-142.

Holland, J., 2004. The environmental consequences of adopting conservation tillage in Europe: reviewing the evidence. Agric. Ecosyst. Environ. 103, 1-25.

ISTAT, 2015. Istituto Nazionale di Statistica: http://agri.istat.it accessed: 15-16-02.

Karlen, D.L., Varvel, G.E., Bullock, D.G., Cruse, R.M., 1994. Crop rotations for the 21 st century. Adv. Agron. 53, 1-45.

Kassam, A., Friedrich, T., Shaxson, F., Pretty, J., 2009. The spread of Conservation Agriculture: justification, sustainability and uptake. Int. J. Agric. Sustain. 7, 292-320

Keeney, D.R., Nelson, D.W., 1982. Nitrogen in organic forms. In: second ed., In: Page, A.L., Miller, R.H., Keeney, D.R. (Eds.), Methods of Soil Analysis, Part 2, Chemical and Microbiological Properties, Agronomy Monograph. vol. 9. American Society of Agronomy, Madison, WI, pp. 643-698.

Kong, A.Y., Fonte, S.J., van Kessel, C., Six, J., 2009. Transitioning from standard to minimum tillage: trade-offs between soil organic matter stabilization, nitrous oxide emissions, and $\mathrm{N}$ availability in irrigated cropping systems. Soil Till. Res. 104, 256-262.

Krause, M.A., Black, J.R., 1995. Optimal adoption strategies for no-till technology in Michigan. Rev. Agric. Econ. 17, 299-310.

López-Bellido, R.J., Lopez-Bellido, L., Benítez-Vega, J., López-Bellido, F.J., 2007 Tillage system, preceding crop, and nitrogen fertilizer in wheat crop. Agron. J. 99, 59-65.

López-Bellido, L., Muñoz-Romero, V., Benítez-Vega, J., Fernández-García, P., Redondo, R., López-Bellido, R.J., 2012. Wheat response to nitrogen splitting applied to a Vertisols in different tillage systems and cropping rotations under typical Mediterranean conditions. Eur. J. Agron. 43, 24-32.

López-Bellido, L., Muñoz-Romero, V., López-Bellido, R.J., 2013. Nitrate accumulation in the soil profile Long-term effects of tillage, rotation and $\mathrm{N}$ rate in a Mediterranean Vertisol. Soil Till. Res. 130, 18-23.

Lal, R., Kimble, J.M., Stewart, B.A., 1998. Land use and C pools in terrestrial ecosystems. In: Lal, R., Stewart, B.A. (Eds.), Management of Carbon Sequestration in Soil. CRC Press, Boca Raton, FL, USA, pp. 1-10.

Lal, R., 2003. Global potential of soil carbon sequestration to mitigate the greenhouse effect. Crit. Rev. Plant Sci. 22, 151-184

Madejon, E., Murillo, J.M., Moreno, F., Lopez, M.V., Arrue, J.L., Alvaro-Fuentes, J., Cantero, C., 2009. Effect of long-term conservation tillage on soil biochemical properties in Mediterranean Spanish areas. Soil Till. Res. 105, 55-62. 
Mazzilli, S.R., Ernst, O.R., de Mello, V.P., Pérez, C.A., 2016. Yield losses on wheat crops associated to the previous winter crop: impact of agronomic practices based on-farm analysis. Eur. J. Agron. 75, 99-104.

Mazzoncini, M., Di Bene, C., Coli, A., Antichi, D., Petri, M., Bonari, E., 2008. Rainfed wheat and soybean productivity in a long-term tillage experiment in central Italy. Agron. J. 100, 1418-1429.

Moonen, A.C., Ercoli, L., Mariotti, M., Masoni, A., 2002. Climate change in Italy indicated by agrometeorological indices over 122 years. Agric. For. Meteorol. $111,13-27$.

Nichols, V., Verhulst, N., Cox, R., Govaerts, B., 2015. Weed dynamics and conservation agriculture principles: a review. Field Crops Res. 183, 56-68.

Pekrun, C., Kaul, H.P., Claupein, W., 2003. Soil tillage for sustainable nutrient management. In: El Titi, A. (Ed.), Soil Tillage in Agroecosystems. CRC Press, Boca Raton, FL, USA, pp. 83-113.

Pellegrino, E., Bosco, S., Ciccolini, V., Pistocchi, C., Sabbatini, T., Silvestri, N., Bonari, E., 2015. Agricultural abandonment in Mediterranean reclaimed peaty soils: long-term effects on soil chemical properties, arbuscular mycorrhizas and $\mathrm{CO}_{2}$ flux. Agric. Ecosyst. Environ. 199, 164-175.

Powlson, D.S., Whitmore, A.P., Goulding, W.T., 2011. Soil carbon sequestration to mitigate climate change: a critical re-examination to identify the true and the false. Eur. J. Soil Sci. 62, 42-55
Sieling, K., Stahl, C., Winkelmann, C., Christen, O., 2005. Growth and yield of winter wheat in the first 3 years of a monoculture under varying $\mathrm{N}$ fertilization in NW Germany. Eur. J. Agron. 22, 71-84.

Soil Survey Staff, 2010. Keys to Soil Taxonomy, 11 th ed. United States Department of Agriculture, Washington.

Steel, R.G.D., Torrie, J.H., Dickey, D.A., 1997. Principles and Procedures of Statistics: a Biometrical Approach. McGraw-Hill, New York.

Tozer, P.R., 2010. Measuring the efficiency of wheat production of Western Australian growers. Agron. J. 102, 642-648.

Vallebona, C., Pellegrino, E., Frumento, P., Bonari, E., 2014. Temporal trends in extreme rainfall intensity and erosivity in the Mediterranean region: a case study in southern Tuscany, Italy. Clim. Change 128, 139-151.

Van den Putte, A., Govers, G., Diels, J., Gillijns, K., Demuzere, M., 2010. Assessing the effect of soil tillage on crop growth: a meta-regression analysis on European crop yields under conservation agriculture. Eur. J. Agron. 33, 231-241.

Zadoks, J.C., Chang, T.T., Konzak, C.F., 1974. A decimal code for the growth stages of cereals. Weed Res. 14, 415-421. 